(b6)

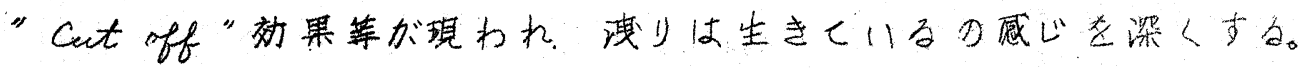

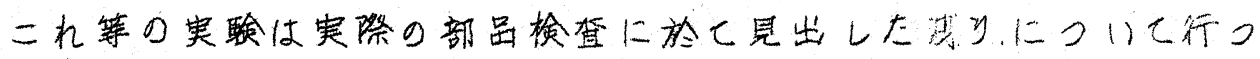

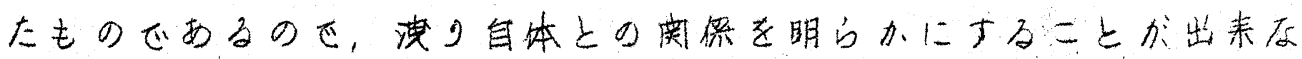
(。二の現象を通して浅り探しの本盾で西る尊管の気体の流れにつ いと注意を喚起したいと恵い。二つに記述した。

$$
\text { 29. } 8,16
$$

拉散ポンプ油を試験し乍ら蒸滔する方法

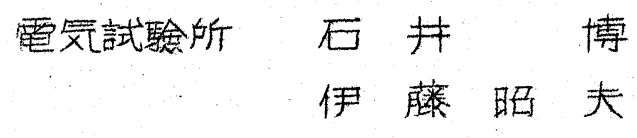

A new method to distillate diffusion pump oil continuously in high vacuum.

$$
\text { Hirashi ISHII, Akio ITO. }
$$

A continuous distillation of diffusion pump oil was carried vit in high vacuum with a glass apparatus which is characterized by watching the final pressure continuously in course of the operation.

The distillation rate of Di-2-ithyl-hexyl phthalate was $30 \mathrm{c} /$ hour at the final pressiure $4 \times 10^{-6} \mathrm{~mm} \mathrm{Hg}$.

\title{
\&1. 緒、言
}

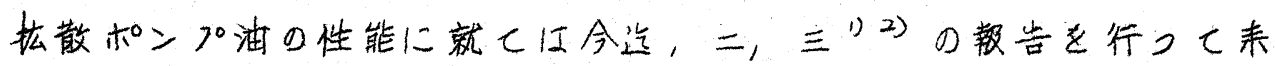

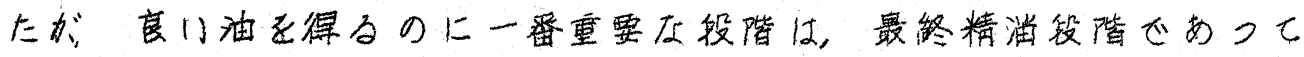

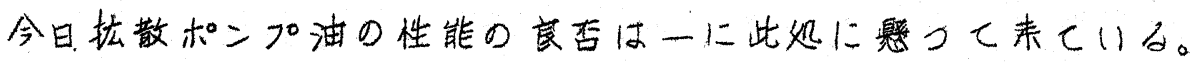

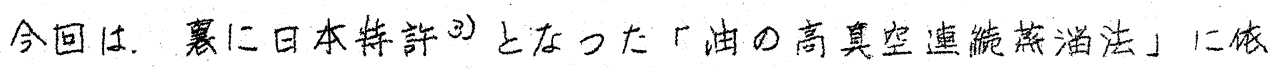


๑H

$\begin{array}{llllllllll}1 & 1 & 1 & 1 & 1 & 1 & 1 & 1 & 1 & 1\end{array}$

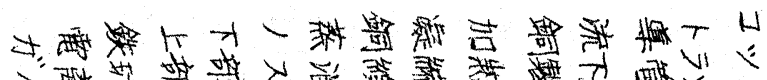

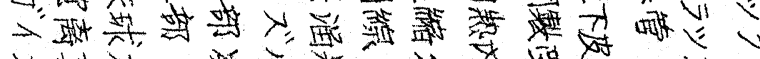

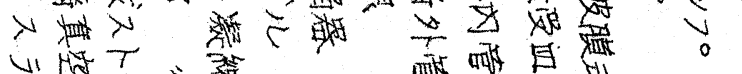

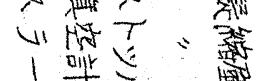

aरf

要

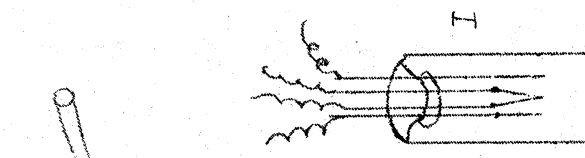

远 新

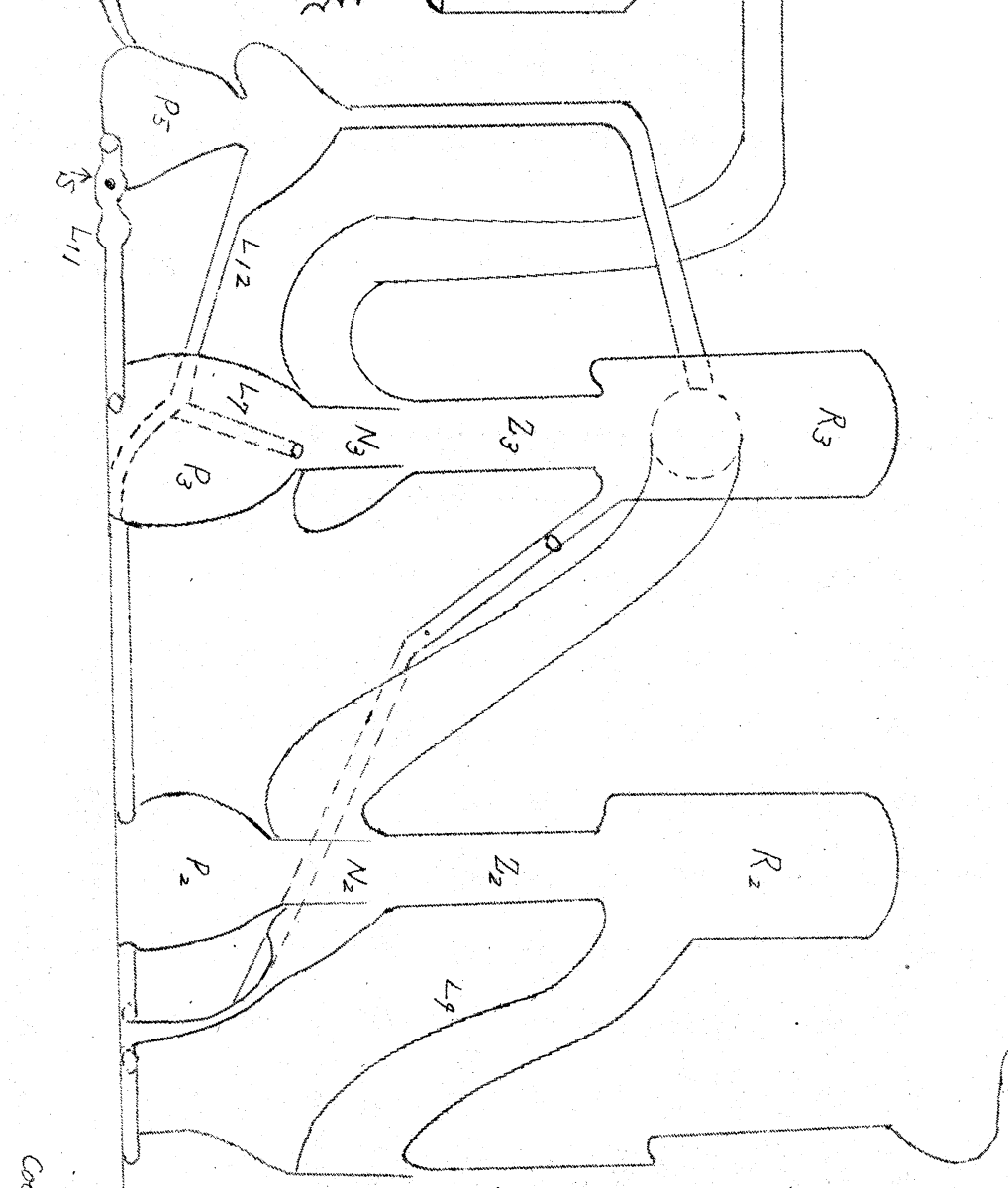

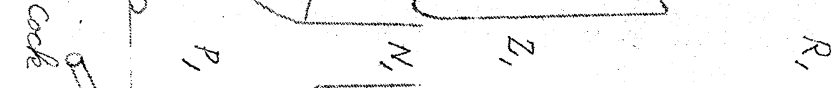

8

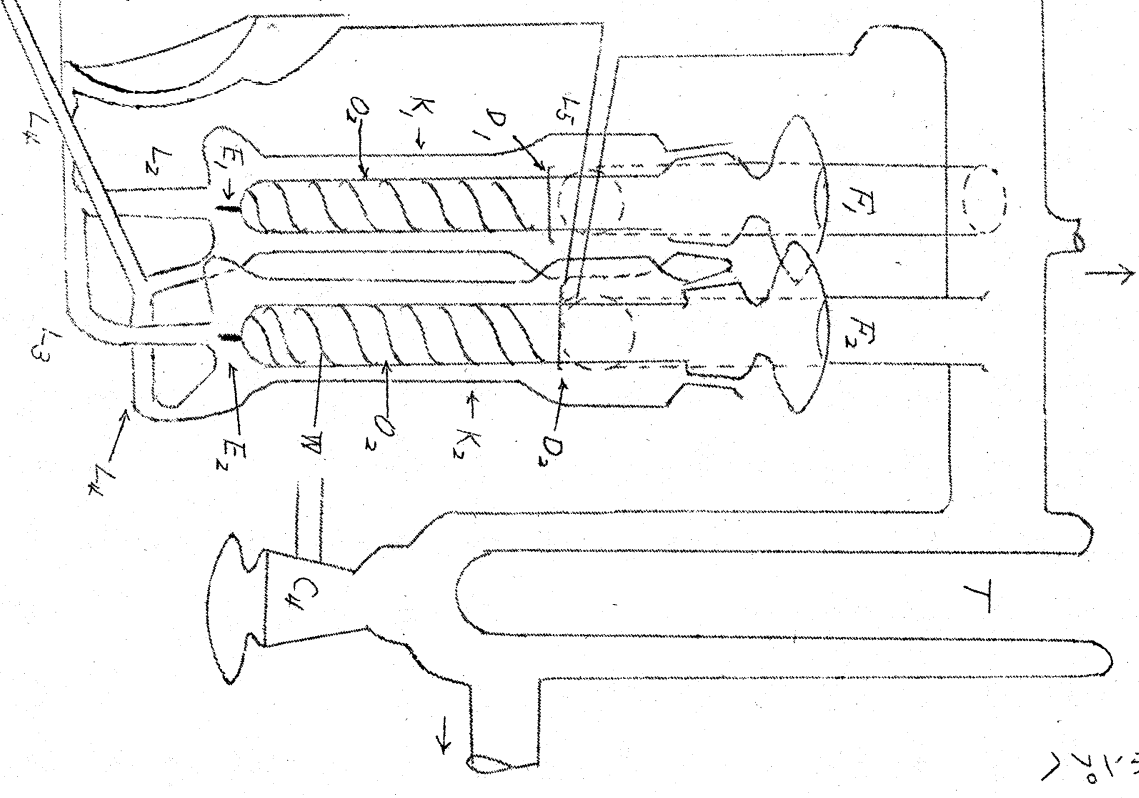

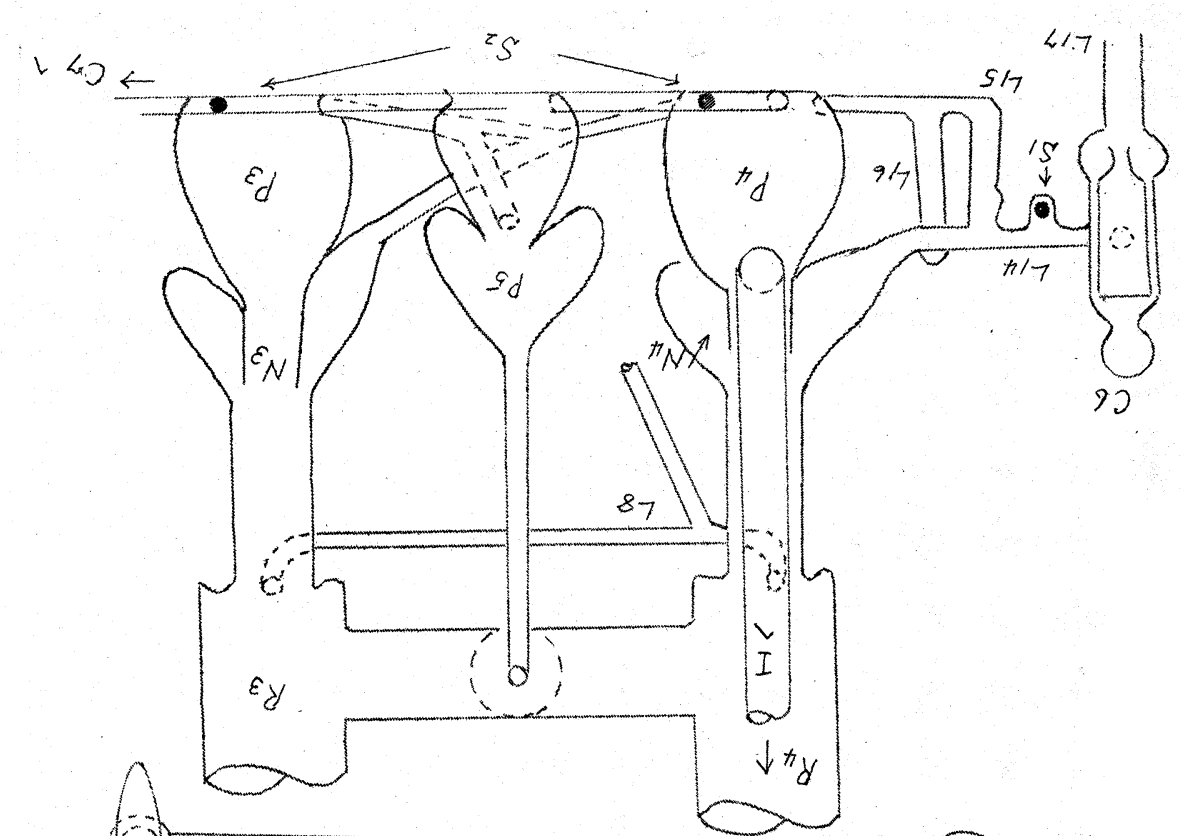
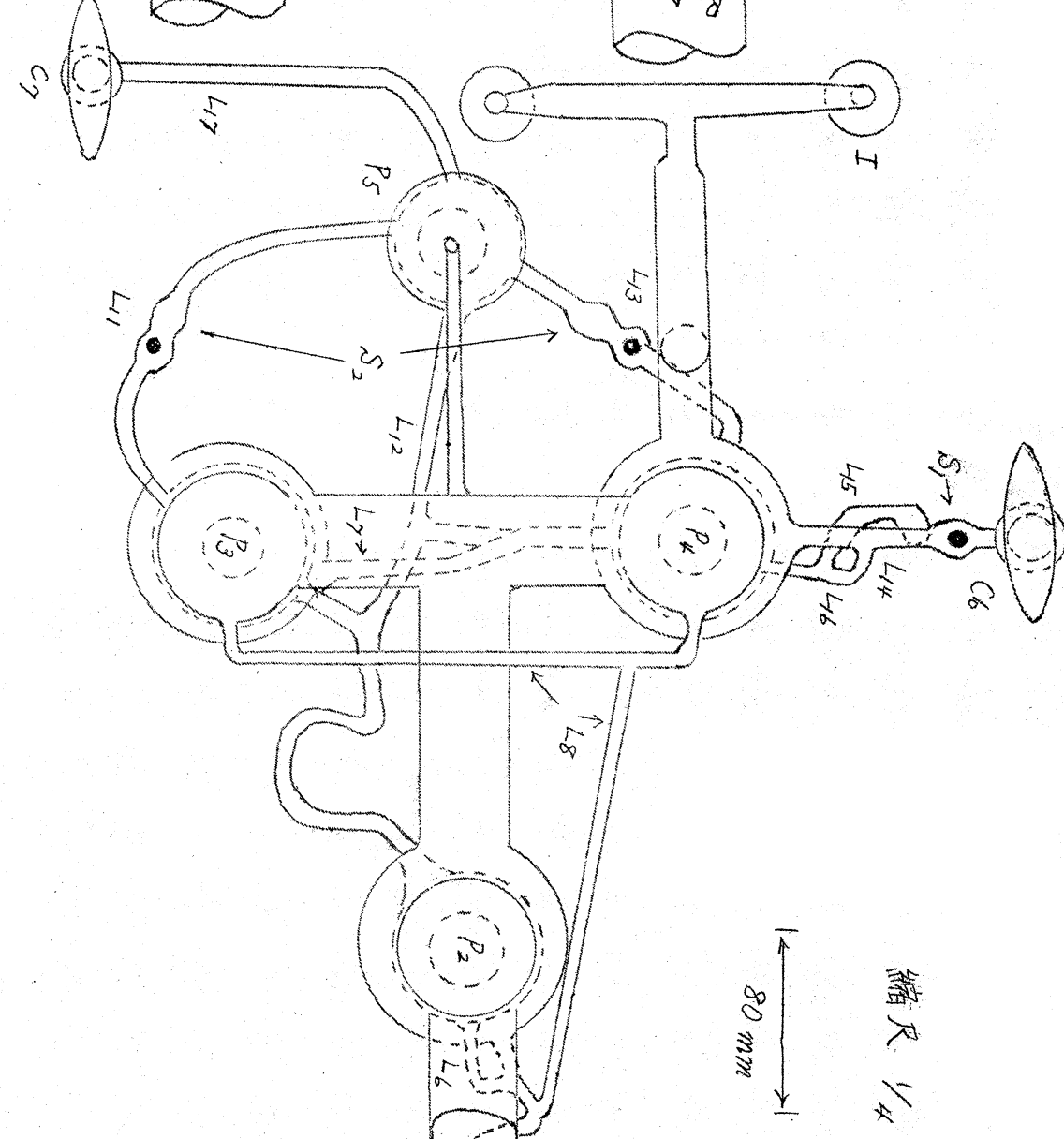

⿶凵

ख 
つて市骐可塑剂 D D.E.H.P ( Di-2-EThyl-Hexyl Phthalate)

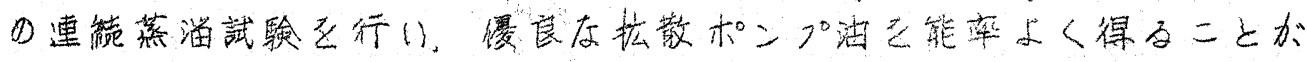
出来たのた，涳在尚D.O.S (Di-2-Ethyl-Hexyl-Sebacate)

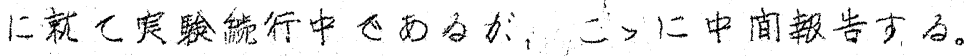

\section{S2. 精滛门原型}

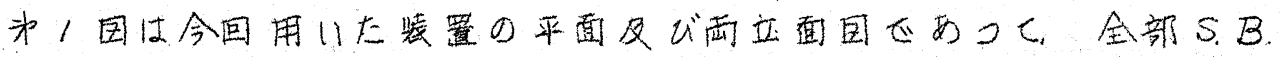

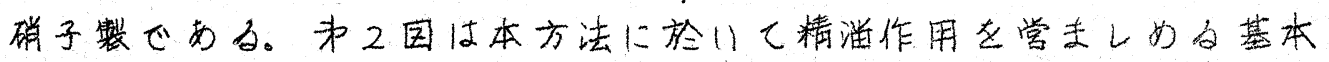

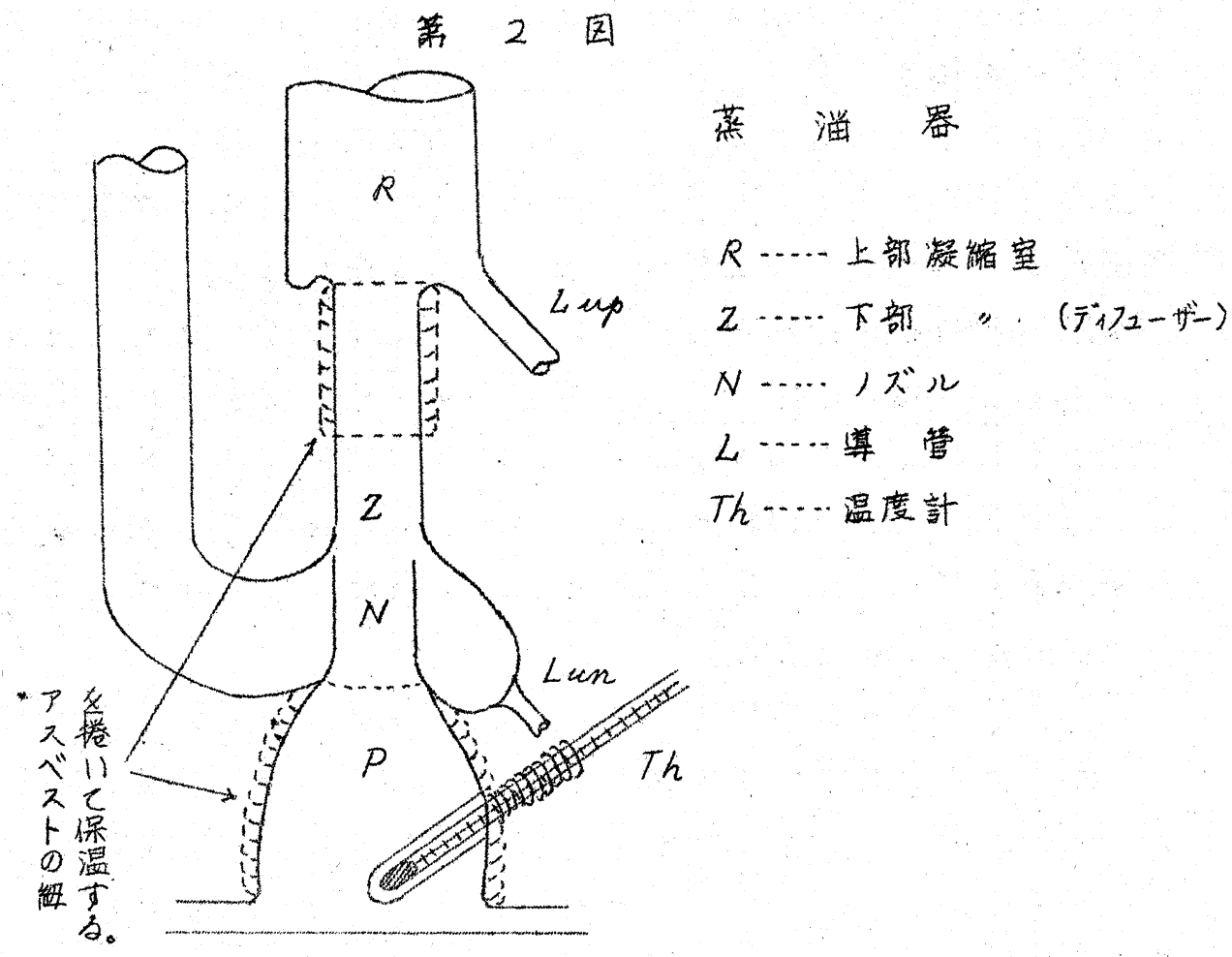

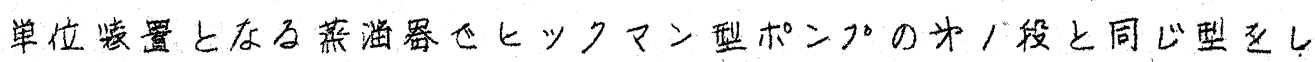
と居る。

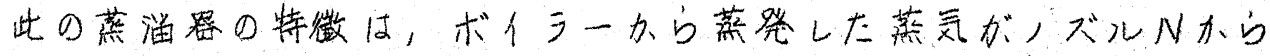

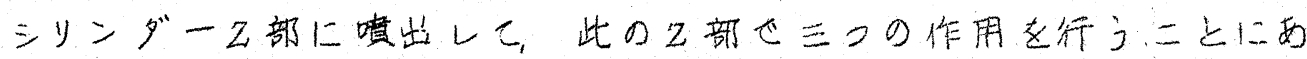
る。即 5 .

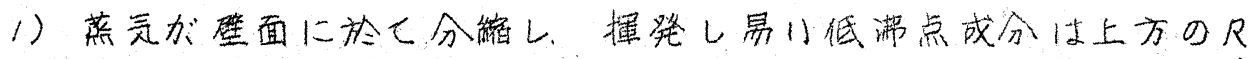




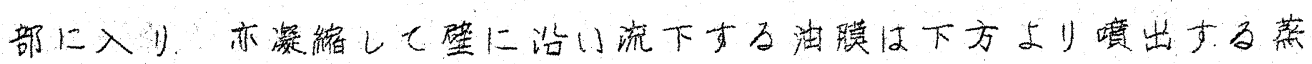

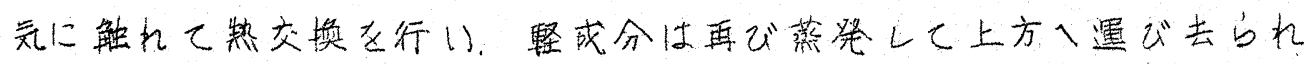

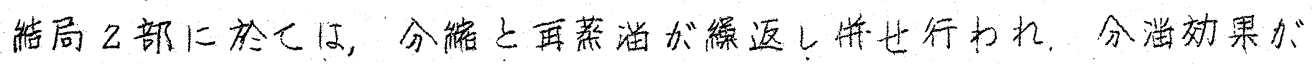
向上し凝縮湿分には低沸点分が少くなる二上です。

2)，上述の作用上依り。低沸点或分は可及的に上方上送方九，R

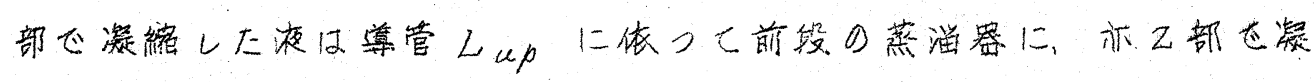

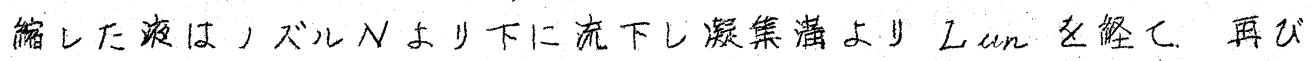
同一のボイう一，若くは别のボイラ一人と自由に送肾込むことが出

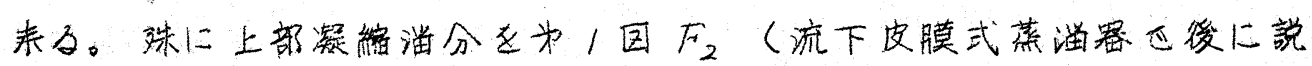
明するつの如き或程度の高さの必要なものに迄供給する二上が出来 るのは大きな作用太西る。尚精垱作用の強化を国及ため、に、乙部を 普通耾散ポン 700 デイつューザ一よ上長くし、且上部を保温して 低沸点成分之成子可く上部Rに送り込力る㥞にした。

本法に於忖子精海作用生非常にダイナミツクなもの厄，氮液平衡

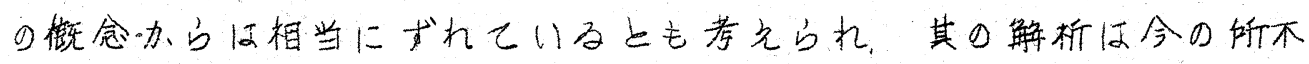

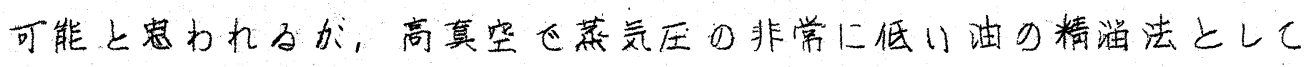

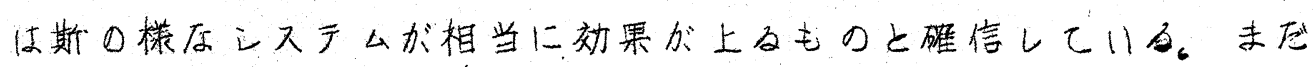

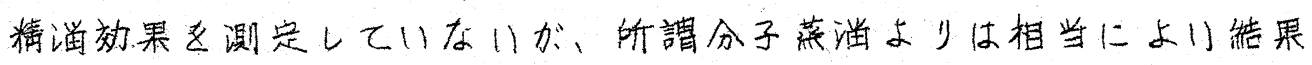
汃得的れるものと考える。

3)最後の重要な作用はノズルNより喷出した菜氮の行うポンプ

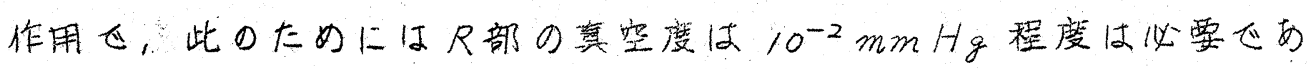

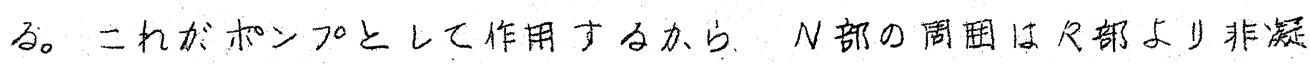

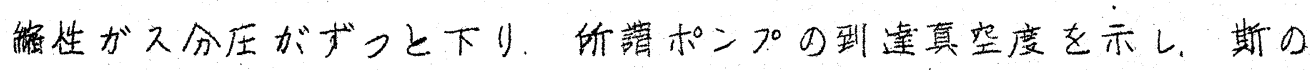

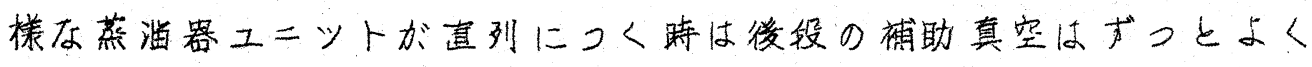

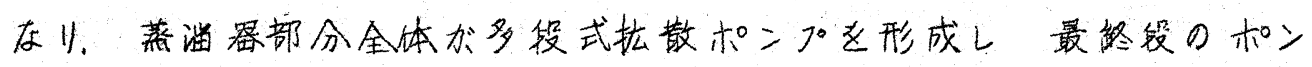

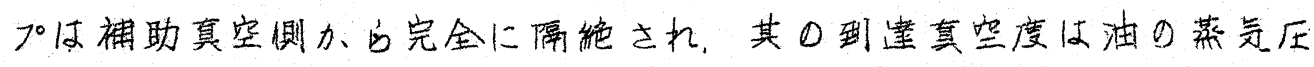

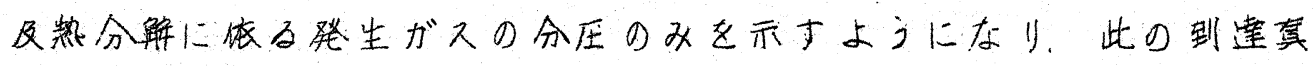

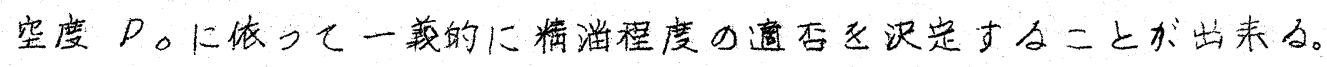

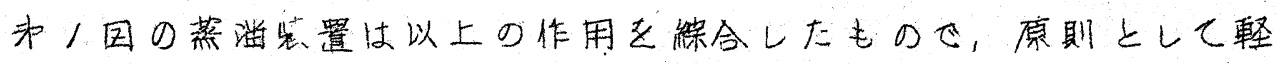

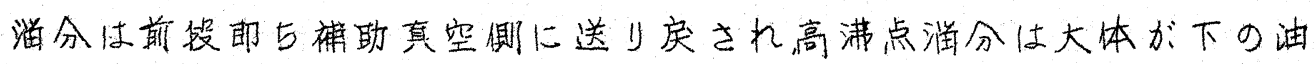




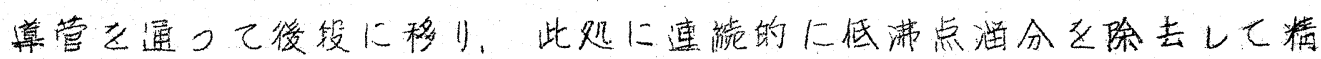
洋分莨得尚仕組になってい子。

\section{§3、装䈏及び操作}

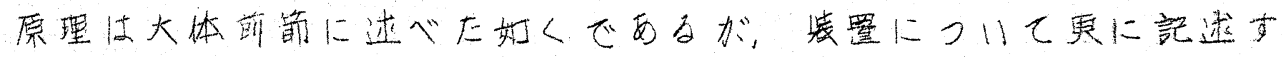
80

\section{1) 補助枪ン 70 䒺}

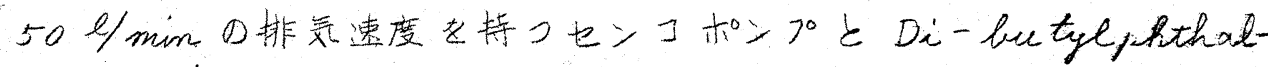
ate老作動油に用いた了时のブースタ一ポンプを連結して補助ポ 70系とし $10^{-4} \mathrm{mmHg}$ を得るようにした。ブースタ一の次にドタ イアイス用のトラツプ（T）在設け，原料油に合まれる未反応めオ クチ儿アルコ一ル，フタ一儿酸等を捕えと二れらに対する排気速度

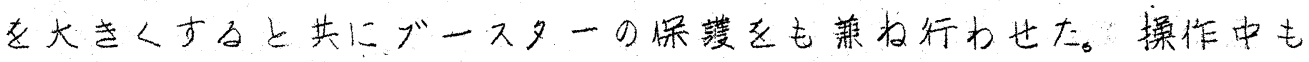

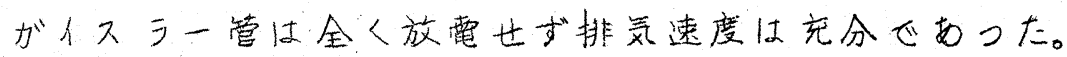

\section{2) ガス拨槽}

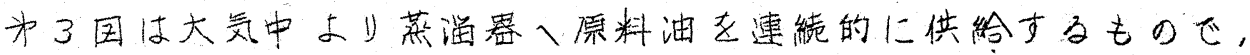
メスレリンダーMに入れた油はコック（c, 作り流入速度を調節さ 机て夕ンク中に入リ此処匹ヒ一タ一

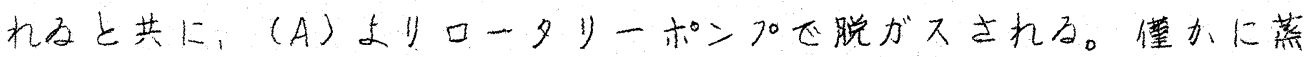

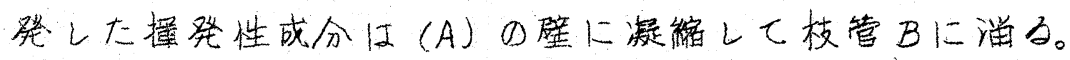

脱がスされると共に予热された原油はコック（C2)より流下皮膜式 葬滔们入流れ込む。コックにはンリコングリースを用りた。

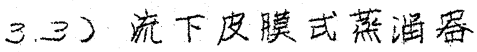

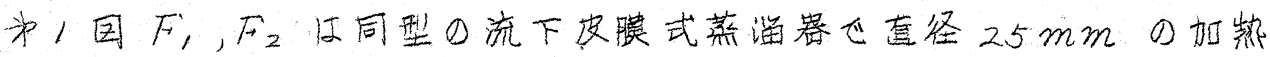

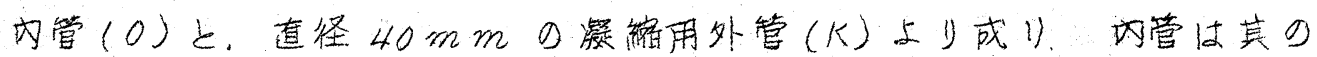

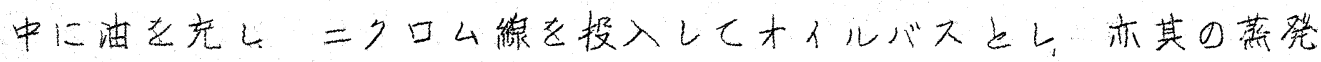

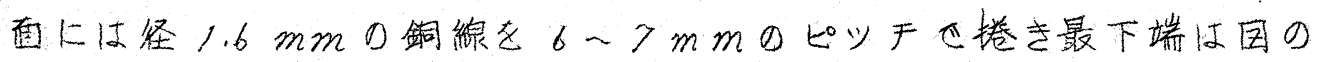

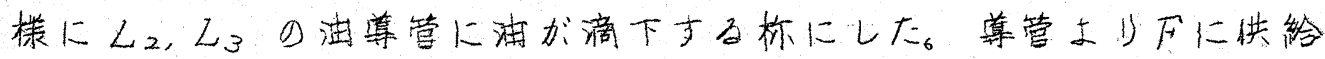

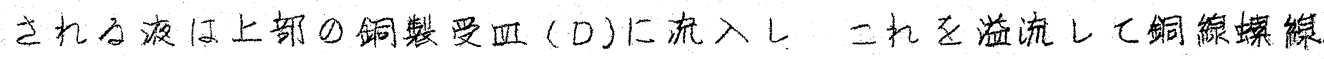

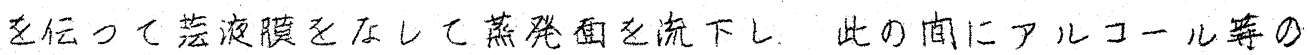


(70)
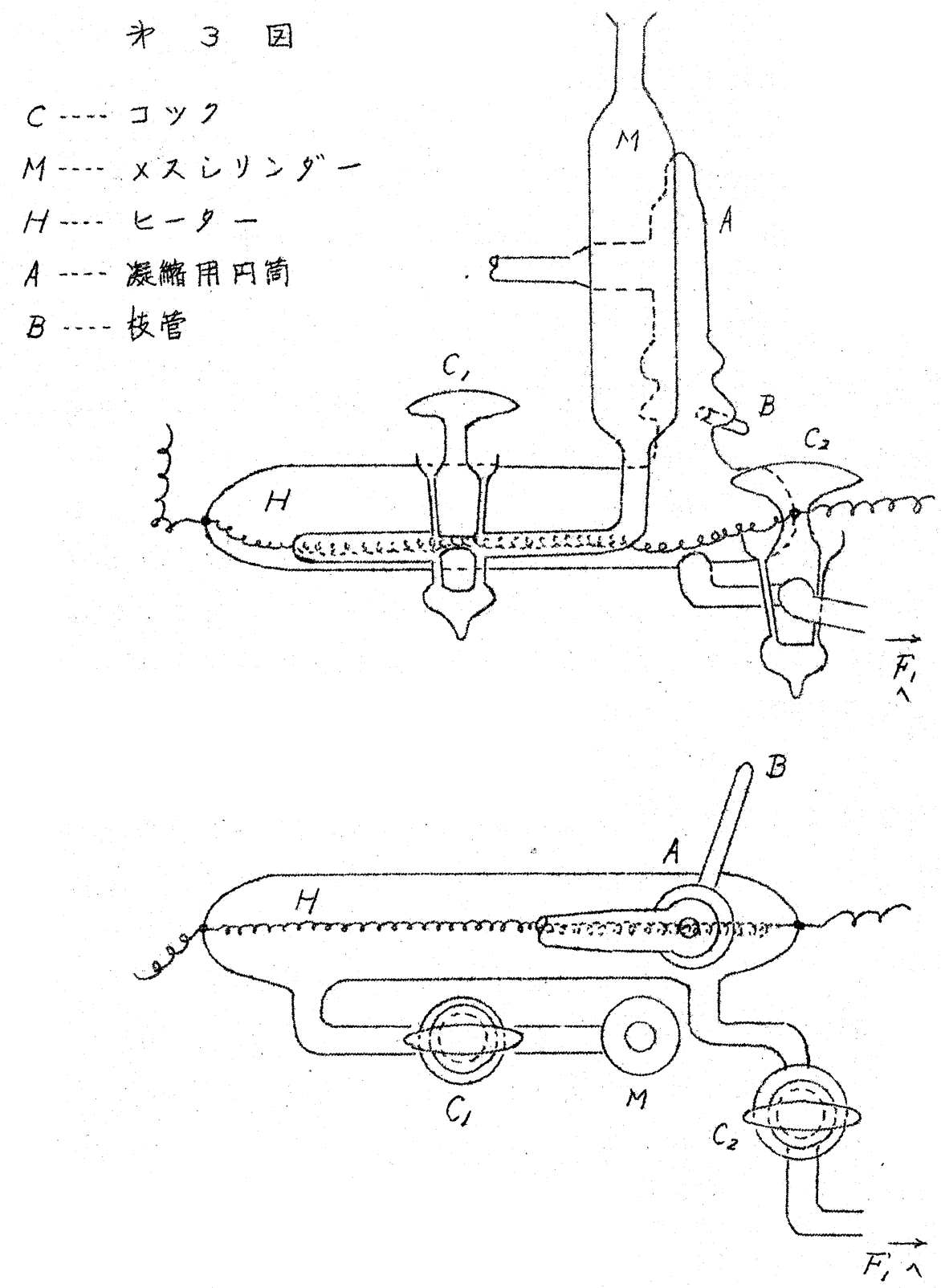

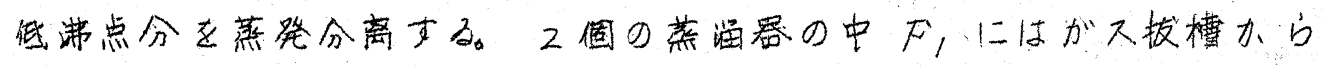

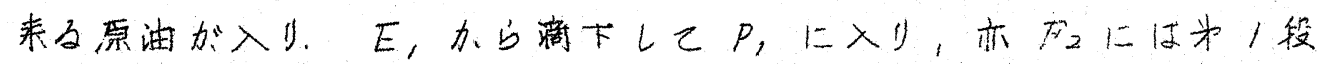

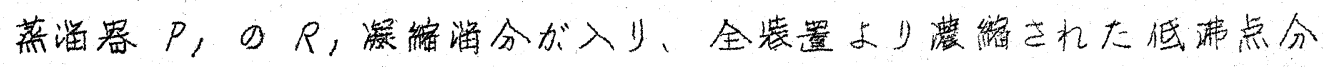

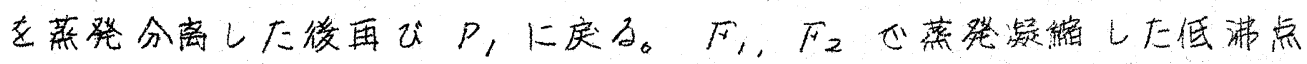

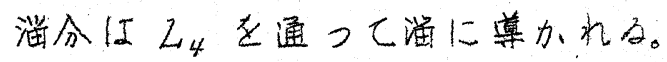




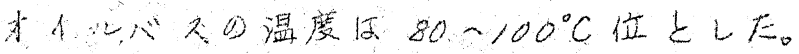

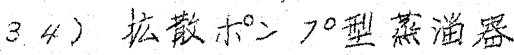

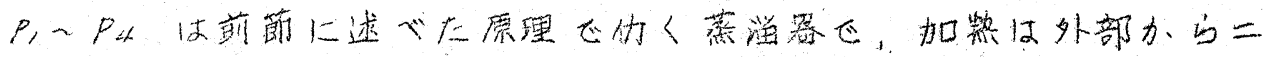

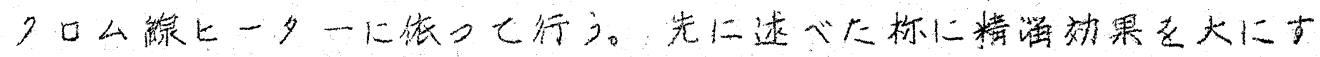

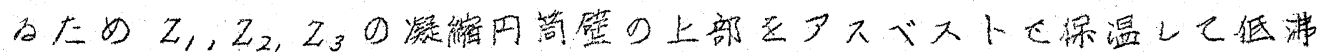

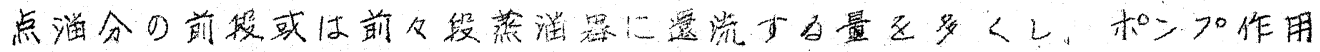

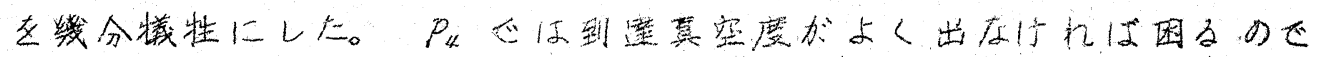

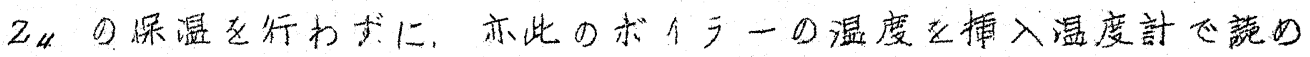

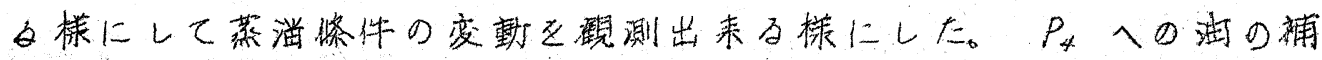

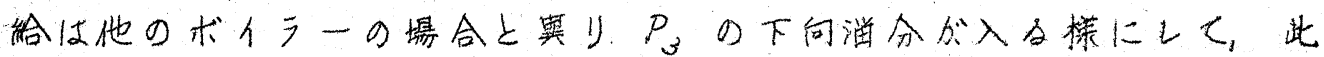

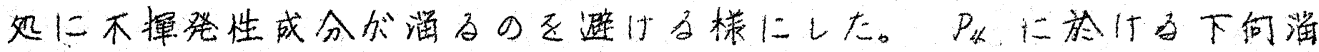

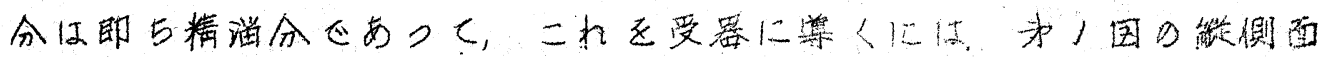

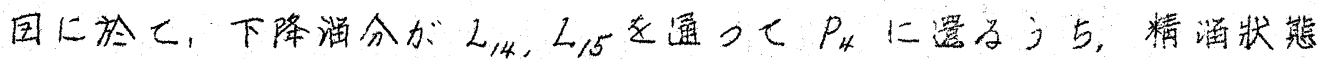

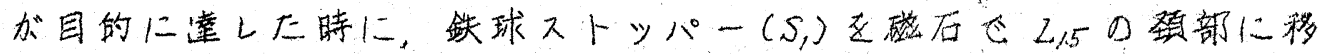

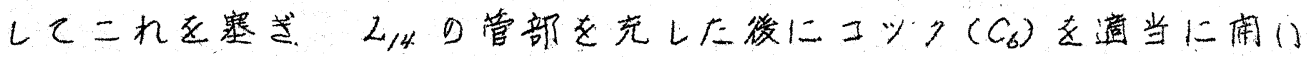

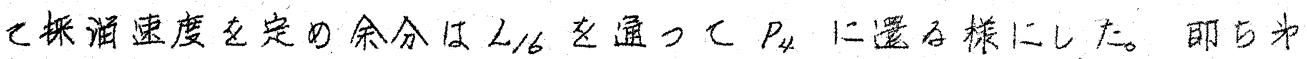
4 蒸涌器分能分抽涌 ( partíal condence, partial take off type)型心斯る之ステムは通常行われていない。

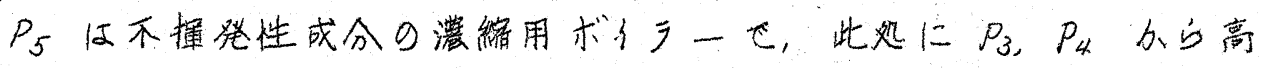

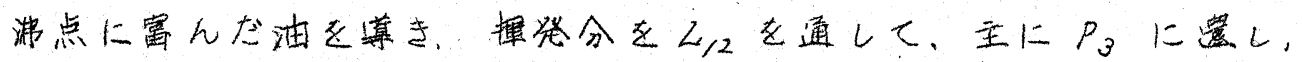

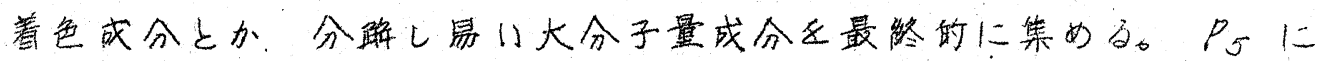

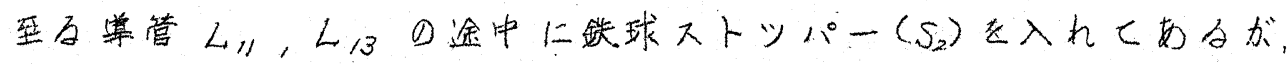

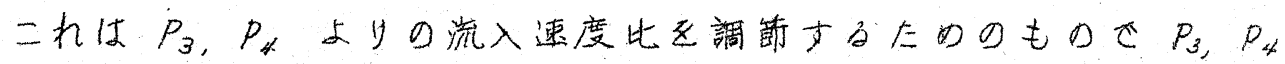
巨，特にP れ出来ないよjに䔔当に絞る二とが必要である。

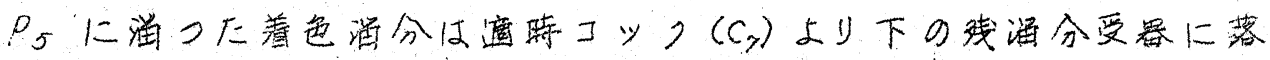

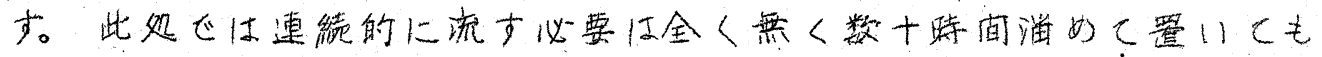
好り样㐫市。

3.5) 真空度测定。

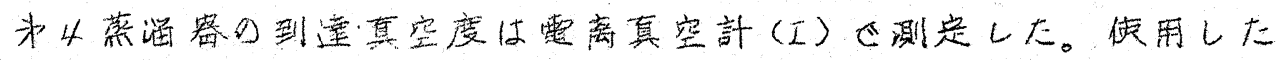


(72)

管球は純タンダステンフィラメントのFogel 型の毛のを用いた。

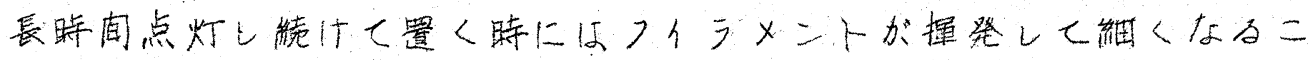

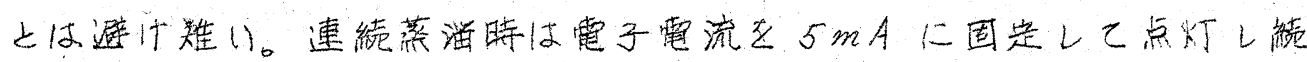

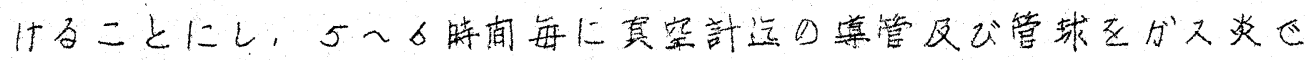

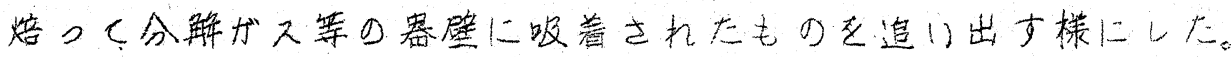

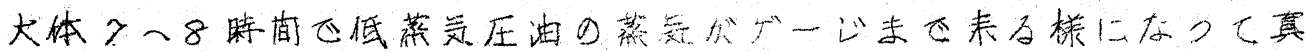

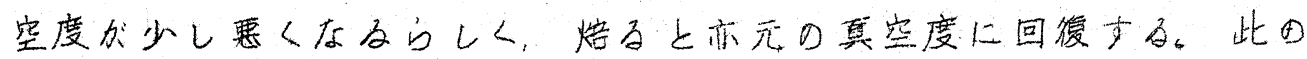

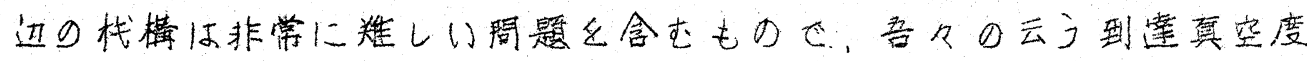

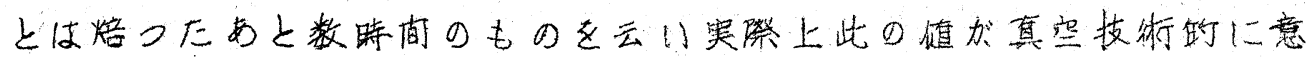
味功するものと思う。

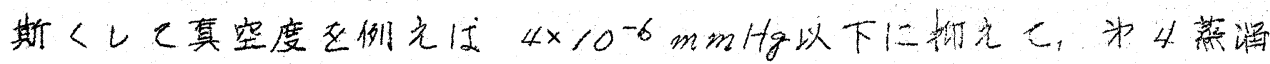

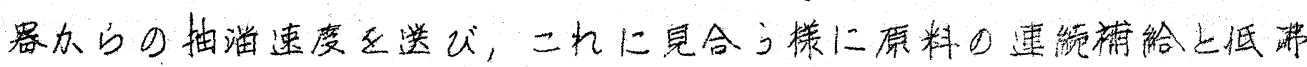
点谓分の抽滔速度を加减して完全な連緢菜滔操作汃行える訳心的る。

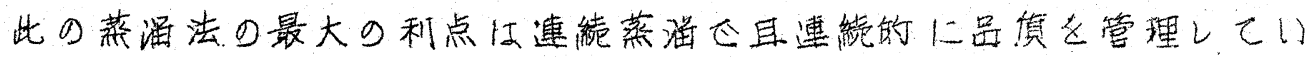

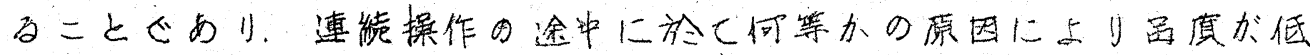

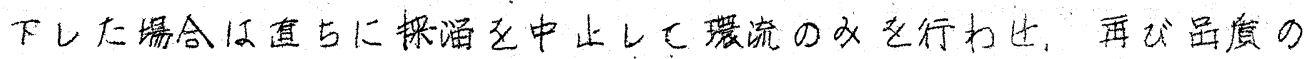

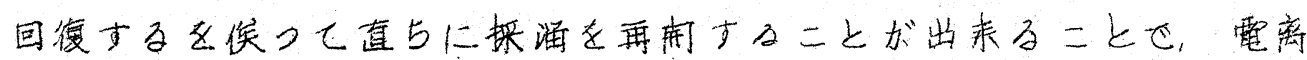
真空計区もニタ一をして自動制御も不可能心はない訳心める。

3.6 ) 洋分取!出し法

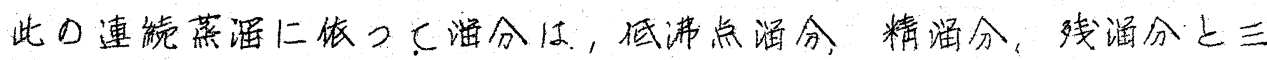

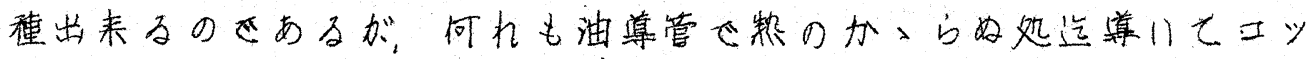
クを通して受赛(事出园) 上落士。

此処で、，别のポンプを用いて容畨(B)を真些に引けてい及のた

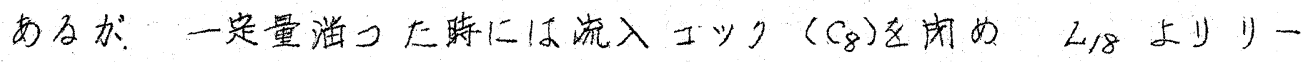

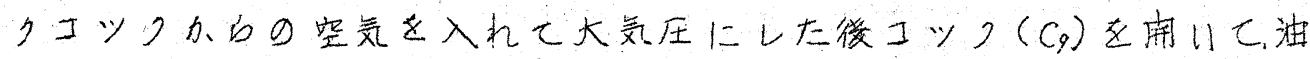

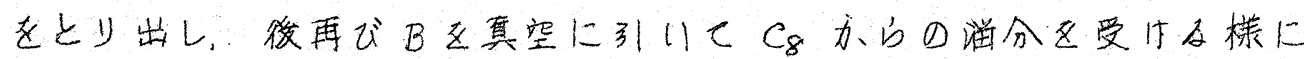
Lた。

二れらの操作せ一番閣題になるのはコツクて、グリースなしたは

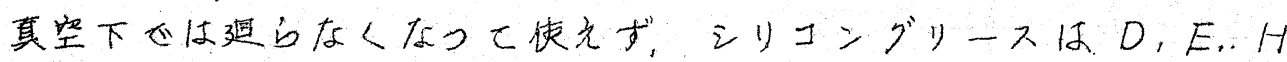

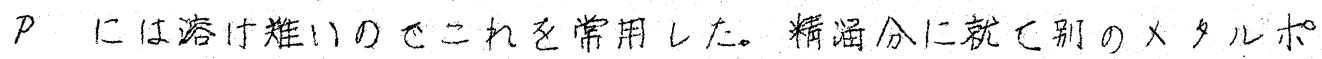




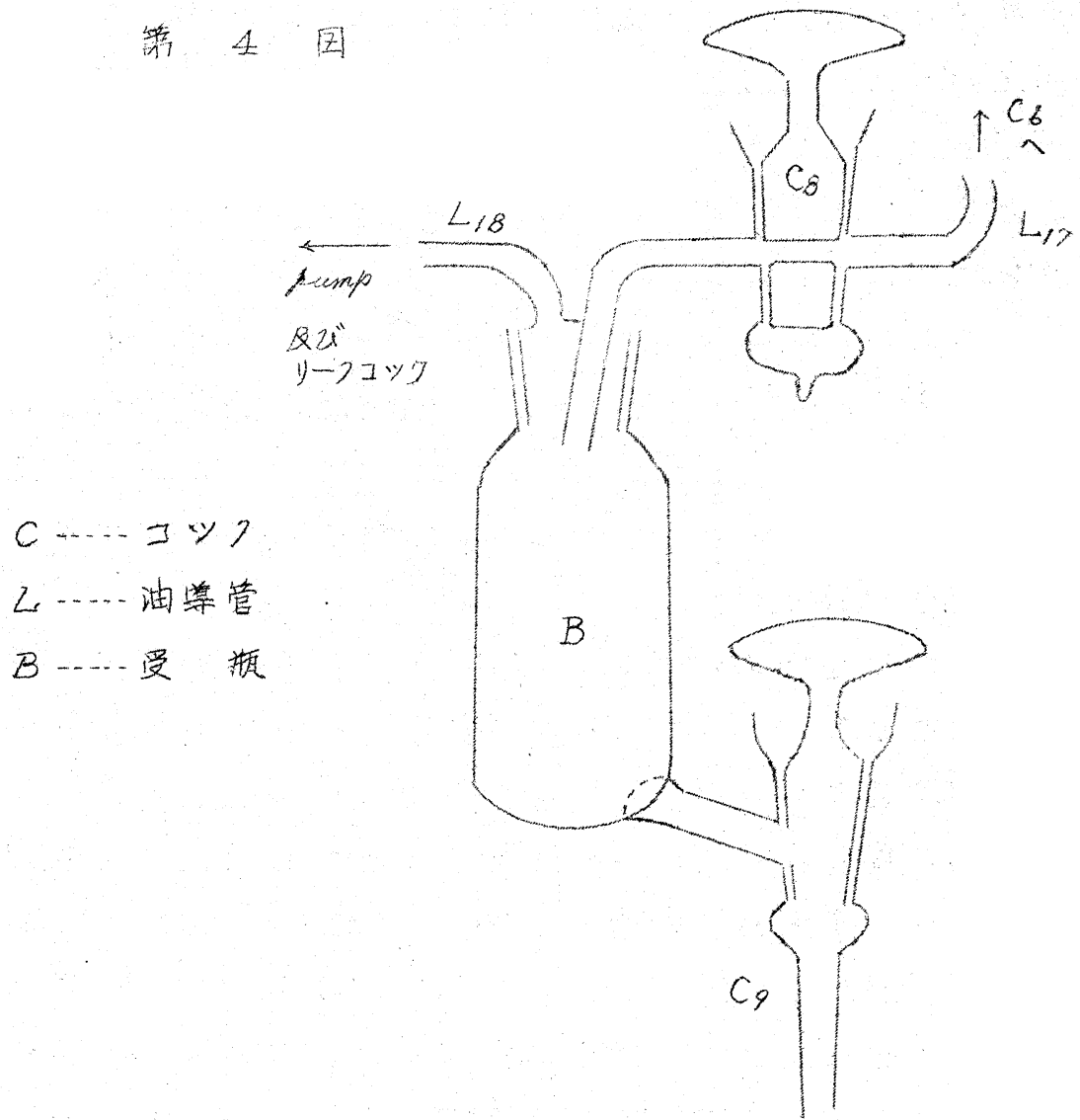

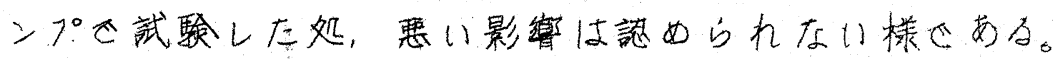

\section{马4 实駼結果}

4.1)採洋しない埸合の到真空度

到逢真空度を決定するのは裤助真空側办白のがスの迹拻散量，液

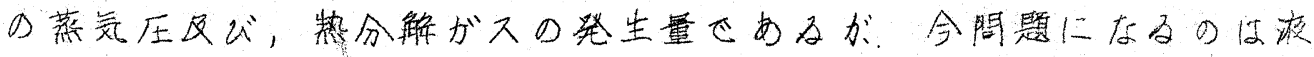

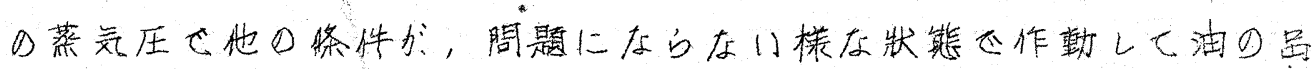

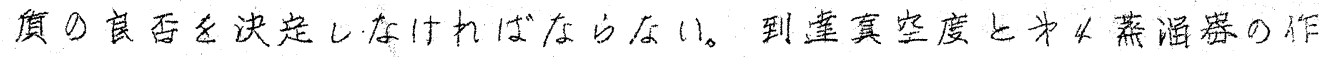

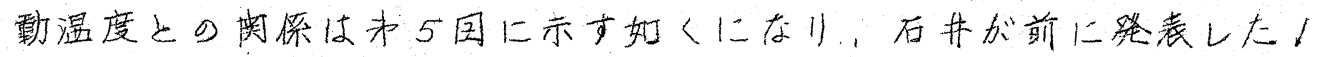

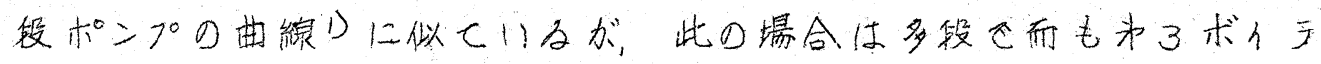

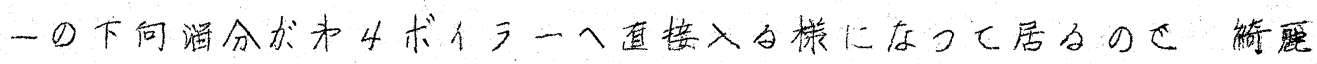

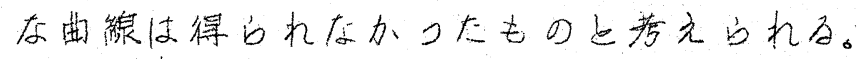




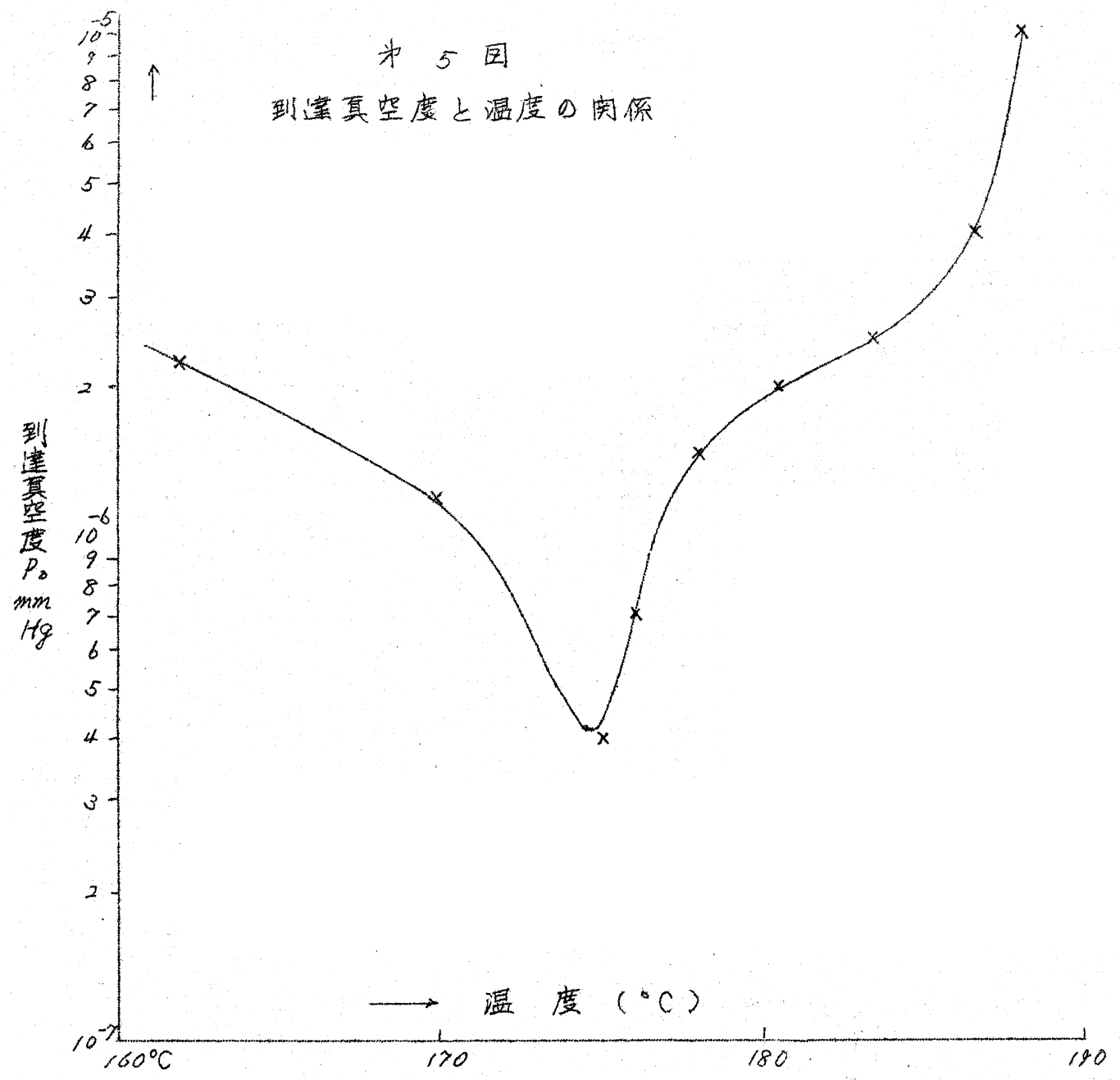

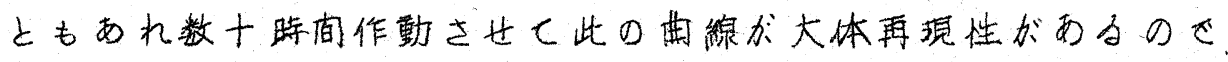
$175^{\circ} \mathrm{C}$ 前後が最も到连真空度のよいニとが判つた。しかし到達真空

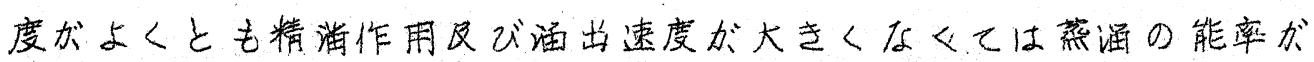

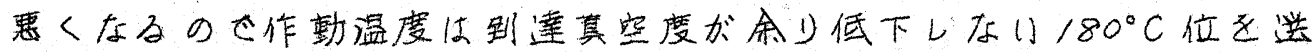
ぶ可きたかるう。

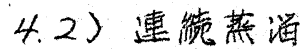

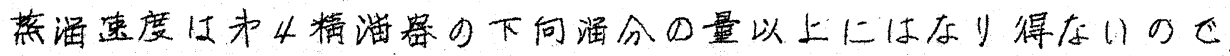
二れを为4ボムラ一の撞入湿度計の証みに对して測つた処：次の值 が得它れた。 


$$
\begin{array}{ll}
178^{\circ} \mathrm{C} & 108 \mathrm{cc} / \mathrm{hr} \quad(=20) \\
180^{\circ} \mathrm{C} & 115 \mathrm{cc} / \mathrm{hr} \\
181^{\circ} \mathrm{C} & 119 \mathrm{cc} / \mathrm{hr} .
\end{array}
$$

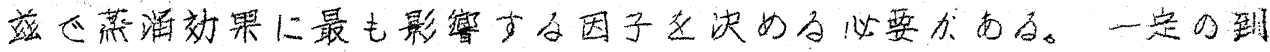

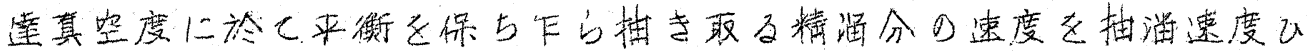

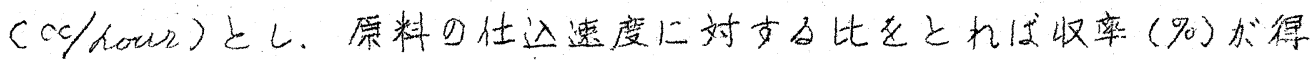

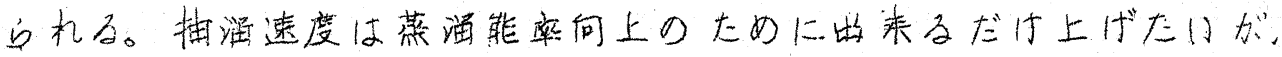

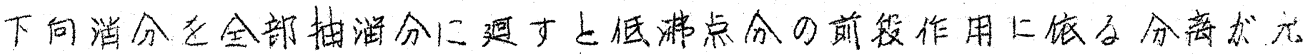

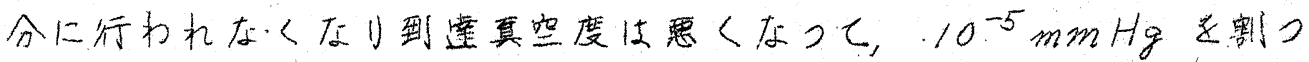

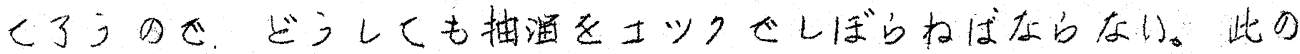

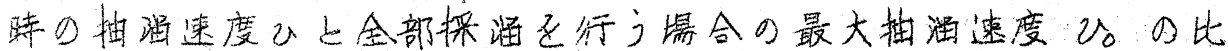

$\left(v / v_{0}\right)=\alpha$ 文抽浊比と才る。

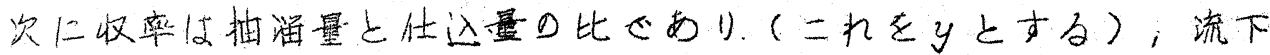

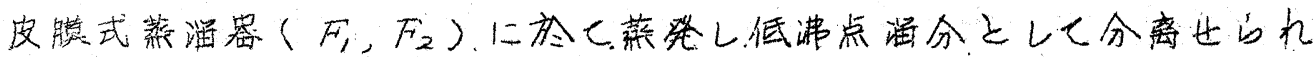

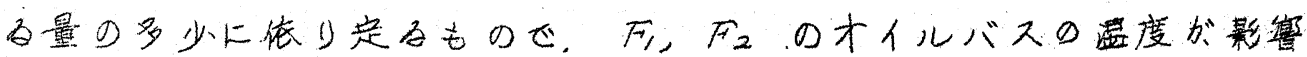
tiso

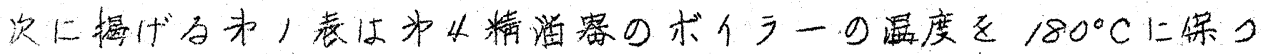

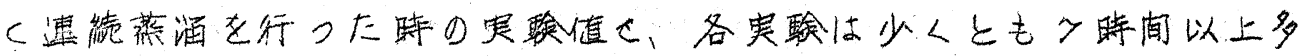

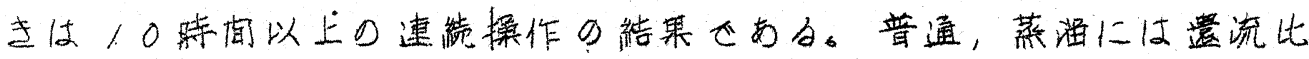

\begin{tabular}{|c|c|c|c|c|c|c|c|c|}
\hline \multirow{2}{*}{$\begin{array}{l}\text { 定涘 } \\
\text { 番 号 }\end{array}$} & \multicolumn{2}{|c|}{$F_{1} F_{2} \emptyset$ 温塺 } & \multirow{2}{*}{$\begin{array}{l}v^{\prime} \\
\operatorname{cothr}\end{array}$} & \multirow{2}{*}{$\alpha_{90}$} & \multirow{2}{*}{$r$} & \multirow{2}{*}{\multicolumn{2}{|c|}{$\begin{array}{c}\text { 到灆真度 } \\
\text { P。 }\end{array}$}} & \multirow{2}{*}{$\begin{array}{c}\text { 収率 } \\
y\end{array}$} \\
\hline & $T$ & $T_{2}$ & & & & & & \\
\hline No. 1 & $\% 1^{\circ} \mathrm{C}$ & $90^{\circ} \mathrm{C}$ & 54 & 47.0 & 1.1 & $1.0 \times 10^{-5}$ & $m m H g$ & 95 \\
\hline$N o, 2$ & 93 & 90 & 43 & 37.4 & 1.7 & $8 \times 10^{-6}$ & " & 89 \\
\hline No. 3 & 98 & 93 & 35 & 30,4 & 2,3 & $7.5 \times 10^{-6}$ & $\Rightarrow$ & 88 \\
\hline No. 4 & 95 & 88 & 35 & 30,4 & 2,3 & $9.0 \times 10^{-6}$ & * & 95 \\
\hline MO 5 & 104 & 101 & 35 & 30.4 & 2,3 & $3.5 \times 10^{-6}$ & " & 83 \\
\hline No. 6 & 104 & 101 & 29 & $25: 2$ & 3,0 & $42 \times 10^{-6}$ & " & 76 \\
\hline
\end{tabular}

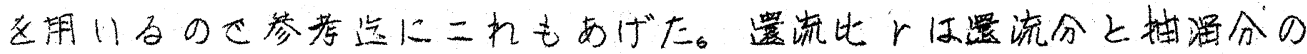

第。，差 
(76)

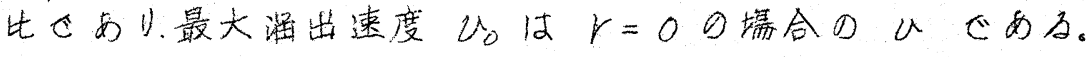

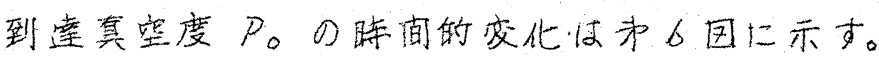

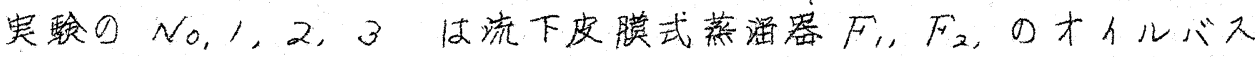

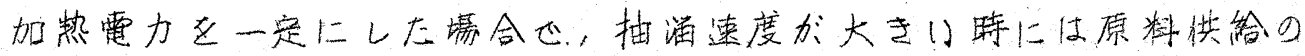

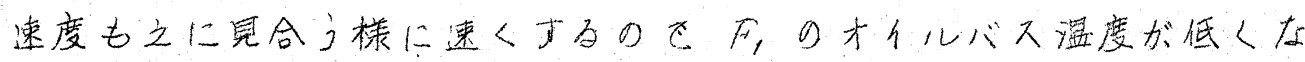

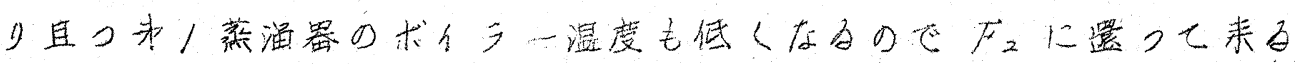
油量も少量上なり従って低沸点分除去が少くなり收率は土くなるが

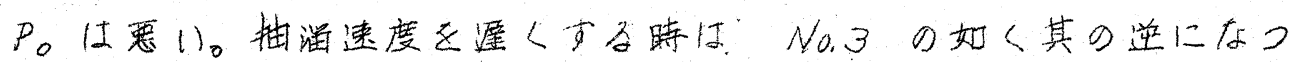
てyは小さくなりP。はよくなる。

此の関係を示儿たものは、Experim. No.1,2、了を国示した武 6国其の/であ。

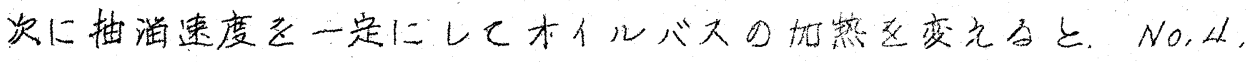

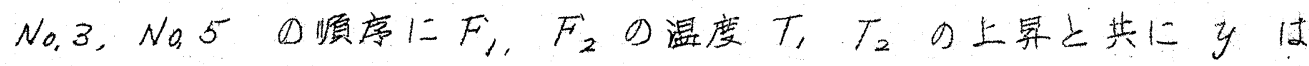
減少してP。广土(なる。(事6国其の开)

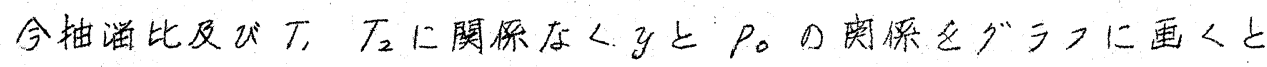

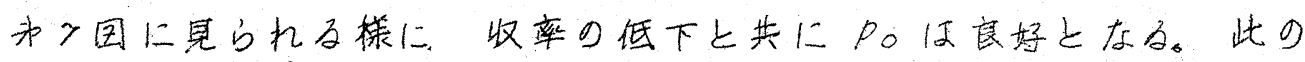

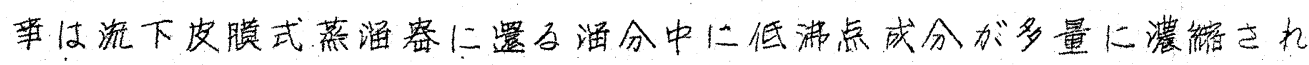

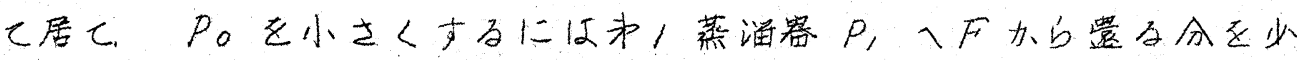
くしてP ，，P4 迄の低沸点分含有量の傾科並に絶对量を少く才る二 之汃最も有效に効いていることを示し，且亦皮膜蒸洋太は分洋効果

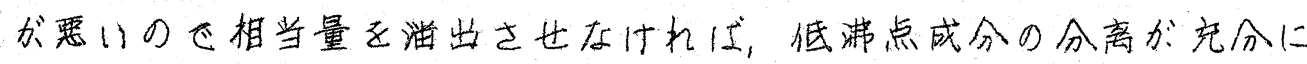
行わ机得ない二とをも示して!る訳ざ，更に品度上く且收率良く精 洋するには尚現在以上に蒸淊钤数を必要之する二とが判る。

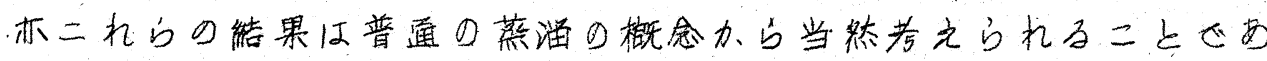

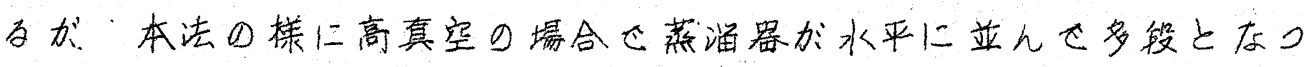
て居る場合上も此の考方を適応出来る二とがはっきりした訳た， Hickman 5) の逆分离現象は此の堧合さして洞題にならない二と を示している。

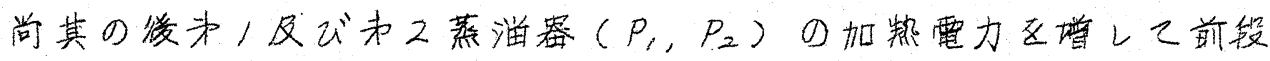

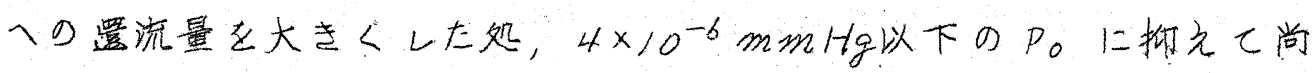
(232) 


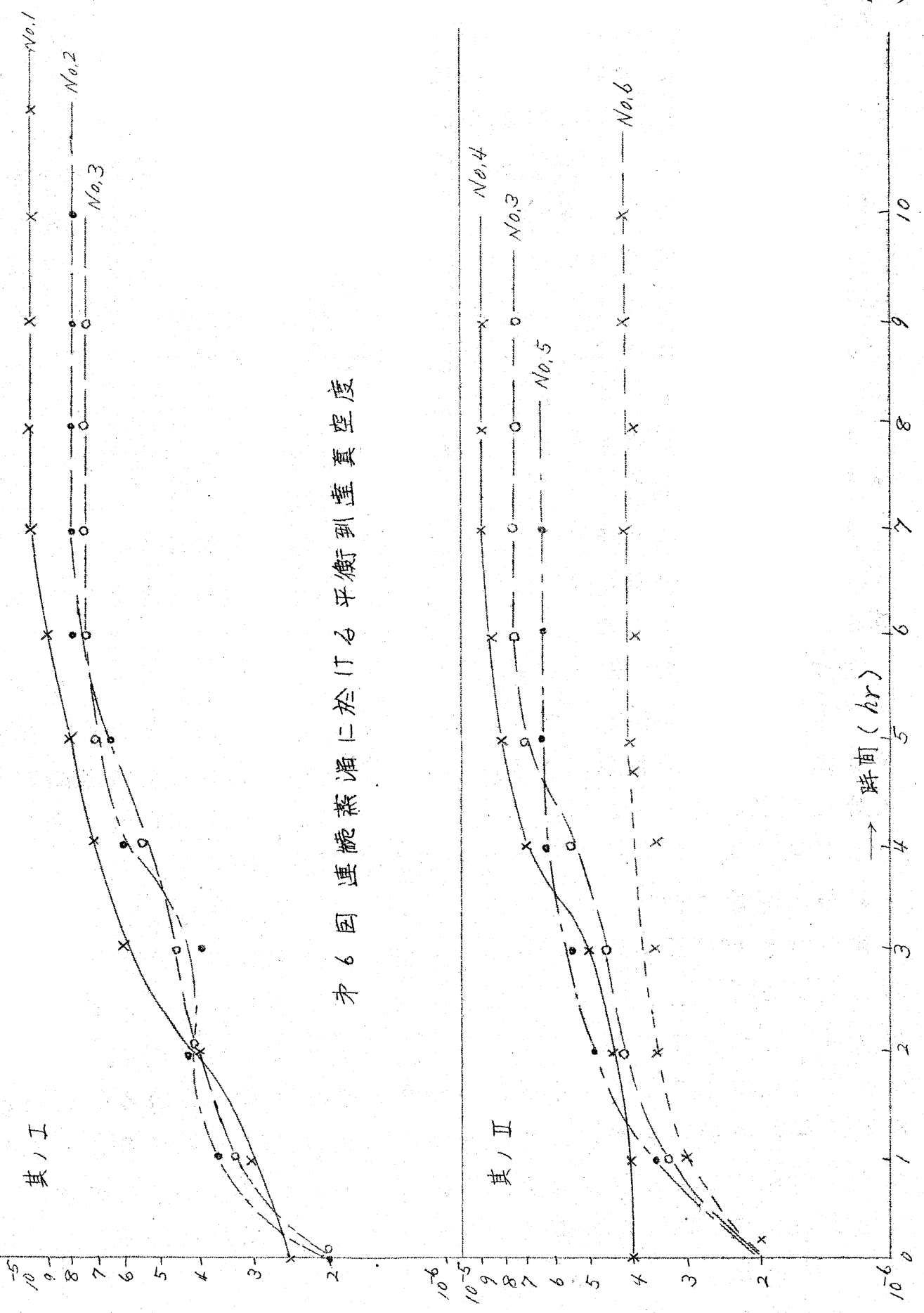

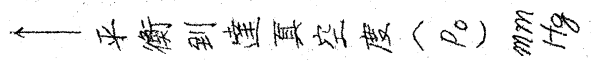


抽滔速度35 c/ h几造上げる二と加出来た。

\section{§5. 精滔分の性稹}

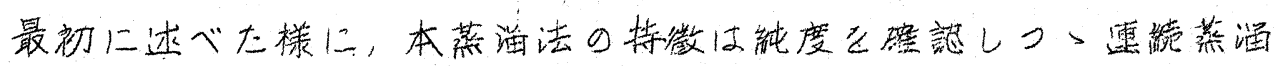

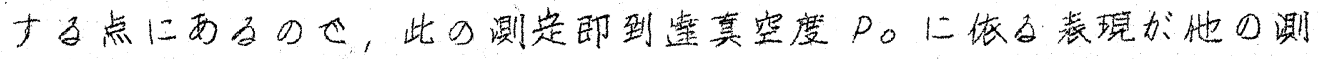

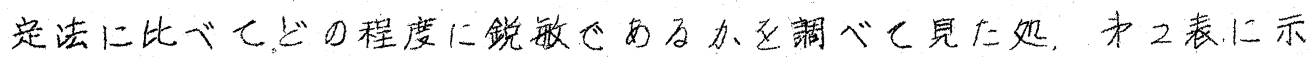

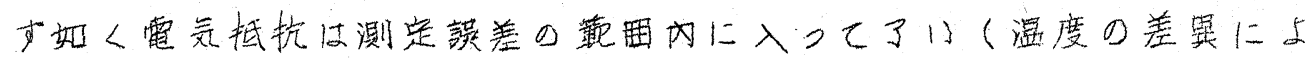

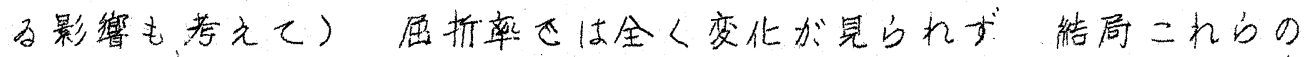
方法では原油と精洋分との相異は見的れるが $10^{-5} \mathrm{mmHg}$ 以下のP。 を示す样な極加て精謷された油の純度を調べる二とは困䊒でると 云つとよく，此の意味てもきP。測定は拻散ポンプ油に对して直接 必要なジ一夕心゙ある許りでなく，可塑剂としての純度测定にも，实

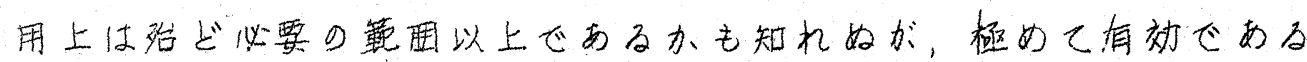
と考えられる。

\begin{tabular}{|c|c|c|c|c|c|}
\hline 消 分 $\left(P_{0}\right)$ & 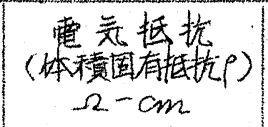 & $\begin{array}{c}\text { 测定湿度 } \\
{ }^{\circ} \mathrm{C}\end{array}$ & 剭 & 折 & 率 \\
\hline $2 \times 10^{-6} \mathrm{~mm} \operatorname{tg}$ K下 & $4.9 \times 10^{11}$ & 23,2 & \multirow{4}{*}{\multicolumn{3}{|c|}{$n_{18^{\circ} \mathrm{C}}^{D}=1.4881$}} \\
\hline $2 \sim 4 \times 10^{-6} \mathrm{~mm} \mathrm{Hg}$ & $3.6 \times 10^{\prime \prime}$ & 22,2 & & & \\
\hline $4-8 \times 10^{-6} "$ & $5,4 \times 10^{\prime \prime}$ & 22,6 & & & \\
\hline $1.0 \times 10^{-5} \mathrm{mmHg}$ & $6.0 \times 10^{11}$ & 21.8 & & & \\
\hline 原 & $3.7 \times 10^{10}$ & 21.8 & Y & $\begin{array}{l}n_{/ 8^{\circ} \mathrm{C}}^{D}= \\
n_{25^{\circ} \mathrm{C}}^{D}=\end{array}$ & $\begin{array}{l}1.4877 \\
1.4845\end{array}$ \\
\hline $\begin{array}{l}\text { * } B . P . \\
183.5^{\circ} \mathrm{C} \text { at } 0.5 \mathrm{~mm} \text { tg }\end{array}$ & & & & $n_{25^{\circ} \mathrm{C}}^{D}$ & 1.4845 \\
\hline$* 183.5^{\circ} \mathrm{C}$ & & & & " & 3.4846 \\
\hline$* 184.0^{\circ} \mathrm{C}$ & & & & $"$ & 1.4848 \\
\hline
\end{tabular}

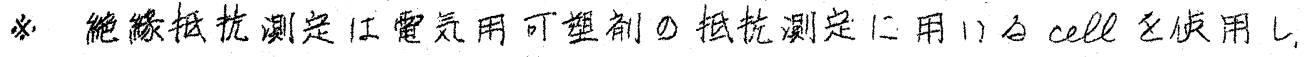
直偏法に作つた。

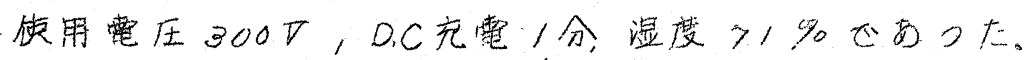




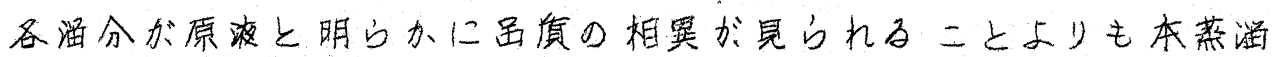
法は相当效果を挙げといると考えてより。

次に实用試验上して德田製作所で”の金蚛製抾散ポンプに用い

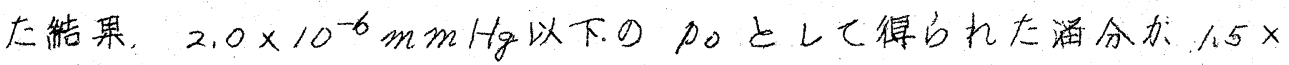

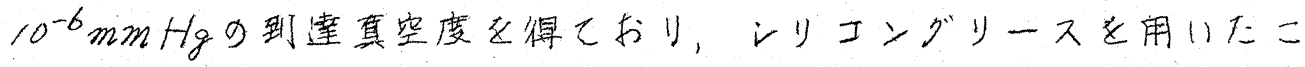

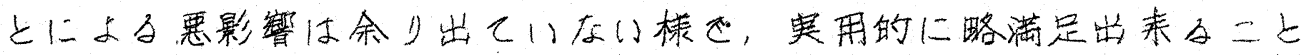
が判つた。

\section{$\$ 6$ 結言}

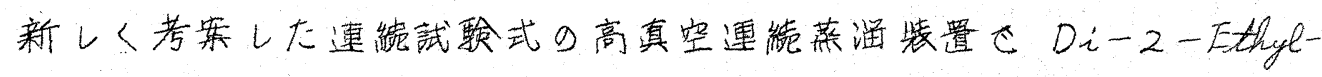
hexyl phthalete (塩化少イ二一兀用可塑剂D.O.P.或はD.E.H.P.)

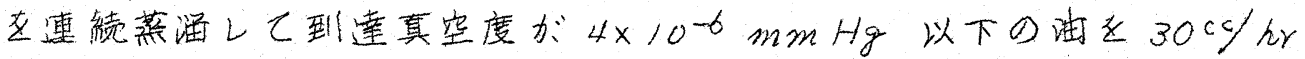

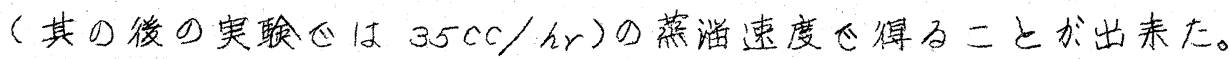

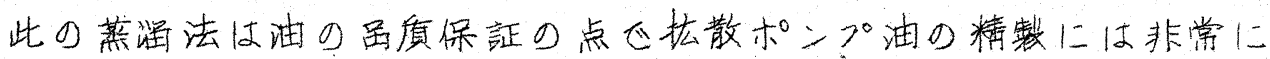
便利太ある。

尚今後 D.E.H.P \& D. O.S. (Di-2. Ethylsebacate) \&o分 離能力女測定し精洋效率を决定す为予定心市。

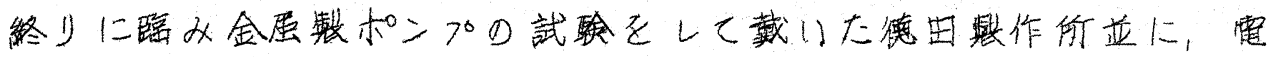

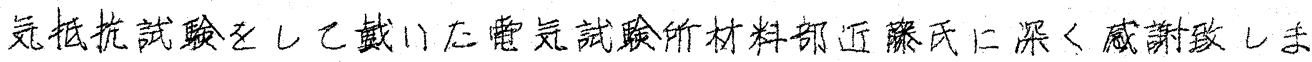
†.

$$
1954.8 \text { 月 }
$$

参考文献

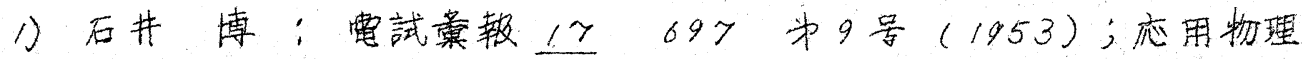

$$
2269(1953)
$$

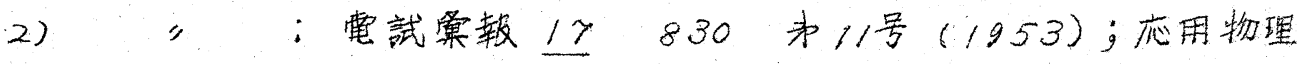

$$
22 \quad 263(1953)
$$

3) " : 日本特部为200995号(昭和28年8月)

4) K.Hickman: I.E.C. 441882 (1952)

5) : R.S.I 22 N0.3 $141(1951)$ 